\title{
EXPERIMENTAL AND NUMERICAL STUDY OF SWIRLING FLOWS AND FLAME DYNAMICS
}

\author{
M. Abricka, I. Barmina, R. Valdmanis, M. Zake \\ Institute of Physics, University of Latvia, \\ 32 Miera Str., Salaspils, LV-2169, LATVIA, \\ e-mail:mzfi@sal.lv
}

\begin{abstract}
The effect of swirling air on the flow dynamics was investigated for the cold non-reacting flows and the flame arising at thermo-chemical conversion of biomass pellets downstream of a cylindrical channel. Under experimental and numerical investigation was the swirling flow dynamics with the primary axial air supply below a biomass layer and swirling air supply above it. The results indicate that for cold flows the swirling air jet outflow from tangential nozzles leads to the formation of a complex flow dynamics which is influenced both by upstream and downstream air swirl propagation near the channel walls, with correlating swirl-enhanced formation of the upstream and downstream axial flows close to the flow centreline depending on the swirling air supply rate. These axial flows can be completely balanced at their stagnation within the axial recirculation zone. It is shown that at equal boundary conditions for the swirling flame and the cold flows the swirling flow dynamics is influenced by the upstream air swirl-enhanced mixing of the reactants below the air swirl nozzles. This determines the formation of a downstream reaction zone with correlating development of the flow velocity, temperature and composition profiles in the downstream flame regions with improved combustion stability. The low swirl intensity in these regions prevents the formation of a recirculation zone.
\end{abstract}

Keywords: swirling flow dynamics, swirl intensity, recirculation zone, biomass gasification, biomass (wood) pellets, combustion.

\section{INTRODUCTION}

Research into the swirling flame flows is of vital importance, since the swirlinduced improvement of flame stability and the swirl-enhanced mixing of the flame components would lead to cleaner combustion and its better efficiency in jet engines, gas turbines and combustors [1-5]. Systematic studies of the swirling flows have shown that the flow structure and stability are highly influenced by the swirl intensity depending on the swirl number $(S)$ in the inlet flow [1]. Increasing the swirl number can result in the vortex breakdown with swirl-enhanced axial flow reversing and improved mixing of the flame components as well as in the formation of a recirculation zone with flow stagnation at the flow axis $[1,6,7]$. Under non-premixed combustion conditions with axial fuel supply and secondary swirling air supply the swirl-enhanced recirculation determines the mixing rate of 
axially injected fuel flow with air swirl leading to the enhanced heating, ignition and combustion of fuel components [1]. At a high swirl level $(S>0.6)$ the formation of the flow structure can be influenced by a columnar flow reversing with a growth in the flow instability, the formation of a precessing vortex core (PVC) and development of pressure oscillations in the flame reaction zone. These oscillations promote the formation of combustion instability and a flame flashback that develops at the turbulent burning fuel velocity exceeding the local velocity in the core flow $[6,8,9]$. Hence, whereas the swirl effect is known to be beneficial for the combustion dynamics, a high swirl level can also lead to some undesirable effects exciting the structural vibrations followed by damaging the technological devices and reduced life of combustors $[4,5]$. The opposite approach to the flame stabilization is to use low-swirl burners $(S<0.2)$ that operate at the swirl intensity well below the vortex breakdown threshold [10]. Such burners produce a nonrecirculating flow with decreased linear axial flow velocity in the downstream regions, and, therefore, with clean and complete fuel combustion in boilers and furnaces owing to low $\mathrm{NO}_{\mathrm{x}}$ and $\mathrm{CO}$ emissions $(<15 \mathrm{ppm})$.

Research into the swirling dynamics is particularly important as related to the thermo-chemical conversion of biomass. With the aim to control and improve the flame stability and combustion efficiency of this process as well as the composition of its products, a systematic complex experimental study and a numerical simulation of the swirling flow formation and its dynamics were carried out. To determine the relevant key factors, experiments were run at the conditions of cold non-reacting swirling flows, and comparison was made with the development of swirling flame at thermo-chemical conversion of batch-size biomass pellets. The swirl level effects on the flow dynamics at equal main conditions of swirl flow formation were compared and analyzed.

\section{EXPERIMENTAL}

The experimental setup (Fig. 1) has been designed to provide detailed studies of the swirling effects on the flow dynamics for cold flow conditions as well as for thermo-chemical conversion of batch-size biomass samples. The main component of the setup for the research of the swirling flow structure and the dynamics of cold non-reacting air flow above the biomass layer is a cylindrical channel (inside diameter $\mathrm{D}=60 \mathrm{~mm}$, total length $\mathrm{L}=600 \mathrm{~mm}$ ) charged with biomass pellets (total mass $120 \mathrm{~g}$ ). The channel is composed of diagnostic sections with special openings (2) for insertion of diagnostic tools into the swirling flow at different distances above and below the swirling air supply nozzles (3). The primary air is supplied to the bottom part of channel (1) through the layer of biomass pellets at the average rate of 20-30 1/min, whereas the secondary swirling air is injected through the tangential air nozzles $(5 \mathrm{~mm}$ in diameter $)$ at the average rate of 30-90 1/min. The air supply rates were controlled and measured using flow meters. The swirling air nozzles are located at the distance up to $\mathrm{L}=140 \mathrm{~mm}(\mathrm{~L} / \mathrm{D} \approx$ $2.3)$ above the base of the empty channel and at $\mathrm{L} \approx 90 \mathrm{~mm}(\mathrm{~L} / \mathrm{D} \approx 1.5)$ above the biomass layer. To estimate the key factors of the swirling flow dynamics and structure for the cold flow conditions, the measurements of axial $(u)$ and tangential $(w)$ velocity profiles were done using a Pitot tube that can be locally inserted into the channel through the openings in diagnostic sections (2). The measurements of 
the flow velocity profiles were performed for different primary and secondary air supply rates as well as for different distances above (L/D) and below (-L/D) the secondary air swirl nozzles (Fig. 1). Swirl number $(S)$ of the inlet air flow was approximately estimated as the relation between the average values of tangential $(\bar{w})$ and axial $(\bar{u})$ velocity components: $S \approx 2 / 3 \cdot \bar{w} / \bar{u}$. The average velocity was estimated from the measurements of flow velocity profiles. The formation of the cold swirling flow dynamics and structure is compared with that for the swirling flame at thermo-chemical conversion of biomass samples for equal basic variable parameters - the primary and secondary air supply rates.



Fig. 1. Schematic of the experimental setup for investigation of the swirl flow formation at cold air flow conditions:

1 - primary axial air supply;

2 - openings for local measurements of the flow velocity profiles;

3 - secondary swirling air supply nozzles.

To carry out the experimental study of the swirl effects on the formation of flow dynamics at thermo-chemical conversion of the batch-size biomass samples, the cylindrical channel combines a biomass gasifier and a combustor, downstream of which the combustion of volatiles is developing [11]. The gasifier is charged with biomass pellets of the total mass of $240 \mathrm{~g}$. The propane flame flow is used to provide an additional heat energy supply into the upper part of a biomass layer at the average power of $1 \mathrm{~kW}$ to initiate gasification and ignition of biomass pellets. The primary air is fed to support the biomass gasification development at average air excess $\alpha \approx 0.4-0.5$, whereas the secondary air at $\alpha>1.5$ is fed to support the combustion of volatiles $\left(\mathrm{CO}, \mathrm{H}_{2}\right)$ produced at biomass gasification.

To estimate the main effects that determine the combustion dynamics and the formation of the swirling flame structure at different stages of the thermal biomass decomposition, in our experiments we carried out complex online measurements of the height of biomass layer in the gasifier, local measurements of the axial and tangential flame velocity components, measurements of the temperature in the flame reaction zone, of the composition of products and the combustion efficiency. The online measurements of the flow velocity profiles with a Pitot tube or a hot-wire probe were provided using a Testo 453 flow meter. The swirl effect on the flame temperature, composition of products and combustion efficiency was measured and analyzed using a Testo-350XL gas analyzer. 


\section{RESULTS AND DISCUSSION}

\subsection{Experimental results on the factors governing the dynamics of cold non-reacting swirling flow and its structure.}

The results of a previous experimental study into the formation of the swirling flame dynamics [11] allows suggesting that - for the given configuration of experimental setup - the secondary swirling air promotes formation of upstream and downstream swirling air flows with the swirl flow reversing from the biomass layer. To confirm the upstream swirl flow formation below the tangential nozzles, experiments were run on the influence exerted by cold air swirl effect on the propane flame. The propane flame was radially injected into the channel (Fig. 1) through the circular openings of diagnostic sections (2) located at different distances (-L/D ratios) below the swirling air inlet port. If the secondary air swirl was not supplied, the formation of a straight propane flame pattern across the channel was observed (Fig. 2a). At a secondary swirling air supply the shape of the flow pattern is disturbed, indicating the swirl-induced deflection of the propane flame flow towards the channel walls and the formation of a swirled propane flame structure (Fig. 2b-f). The swirl-induced modification of the propane flame flow pattern below the secondary air inlet nozzle depends on the air supply rate and the distance of the propane flame flow below the secondary air inlet (-L/D). As seen in Fig. 2, the effect of secondary air swirl on the formation of a flow pattern is observed up to the empty channel base located at a distance $\mathrm{L}=140 \mathrm{~mm}$ below the air swirl nozzle.


Fig. 2. The effect of upstream swirl flow formation on the propane flame pattern below the swirling air nozzles for:

a) $-\mathrm{L} / \mathrm{D}=-0.42 ; \mathrm{q}_{\mathrm{air} 1,2}=0$;

b) $-\mathrm{L} / \mathrm{D}=-0.42 ; \mathrm{q}_{\mathrm{air} 1}=0 ; \mathrm{q}_{\mathrm{air} 2}=60 \mathrm{l} / \mathrm{min}$;

c) $-\mathrm{L} / \mathrm{D}=-0.42 ; \mathrm{q}_{\text {air } 1}=0 ; \mathrm{q}_{\text {air } 2}=90 \mathrm{l} / \mathrm{min}$;

d) $-\mathrm{L} / \mathrm{D}=-0.92 ; \mathrm{q}_{\mathrm{air} 1}=0 ; \mathrm{q}_{\mathrm{air} 2}=90 \mathrm{1} / \mathrm{min}$;

e) $-\mathrm{L} / \mathrm{D}=-2.16 ; \mathrm{q}_{\text {air } 1}=0 ; \mathrm{q}_{\text {air } 2}=90 \mathrm{l} / \mathrm{min}$;

f) $-\mathrm{L} / \mathrm{D}=-2.16 ; \mathrm{q}_{\mathrm{air} 1}=21 \mathrm{1} / \mathrm{min} ; \mathrm{q}_{\mathrm{air} 2}=90 \mathrm{l} / \mathrm{min}$. 
To study in detail the effects of upstream and downstream swirl flow formation on the cold flow dynamics, measurements were carried out for the axial (u) and tangential (w) cold flow velocity profiles at different distances below (above) the secondary air swirl nozzles, and at different distances above the biomass layer. The experiments were carried out at a constant primary air supply rate $(301 / \mathrm{min})$ by varying the secondary air supply rate in the range $30-901 / \mathrm{min}$ thus causing variations in swirl number $(S)$ of the cold non-reacting inlet flow (L/D $\approx 0.3$ ) in the range from $S \approx 1.2$ to $S \approx 2$. Typical cold airflow velocity profiles formed at different distances below and above the secondary swirling air nozzle and different secondary air supply rates are shown in Fig. $3 a-f$.

As can be seen in Fig. 3, the axial and tangential flow components exhibit different behaviour above and below the secondary air nozzle. Close above and below the air swirl nozzle $(\mathrm{L} / \mathrm{D}= \pm 0.3)$ the tangential flow velocity forms a peak at $\mathrm{r} / \mathrm{R} \approx 0.9$ (close to the channel walls) and gradually decays towards the flow axis (Fig. 3b,d,f). At increasing distance below and above the air swirl nozzles the radial swirl flow expands towards the flow centreline with a correlating decrease in the peak and average values of the tangential flow velocity (Fig. 3b,d,f, Fig. 4a). As follows from Fig. 2, a similar swirl flow expansion is observed in the experiments modelling the upstream swirl effects on the propane flame flow.

From the development of swirl flow velocity profiles it can be clearly seen that the upstream swirl propagation is associated with variation in the shape of axial velocity profiles (Fig. 3a,c,e). Below the air swirl nozzle the upstream swirl flow formation slows down the axial flow velocity close to the channel walls (to the minimum, Fig. 3a,c,e) at the radial distance $\mathrm{r} / \mathrm{R} \approx 0.85-0.9$, where the tangential velocity of the upstream flow approaches the peak value (Fig. $3 b, d, f$ ). In contrast, formation of the peak value of the axial flow velocity below the air swirl nozzles is observed close to the flow axis - at $\mathrm{r} / \mathrm{R} \approx 0$ (Fig. $3 a, c, e$ ), where the peak and average values of the tangential velocity of the upstream flow decrease to the minimum value (Fig. 3b,d,f, Fig. 4a,b).

Estimation of the upstream air swirl effect on the formation of axial flow velocity profiles below the air swirl nozzles has shown that the average axial flow velocity approaches the peak value close to the biomass layer $(\mathrm{L} / \mathrm{D} \approx-1.4-1.5)$ where the tangential flow velocity falls to the minimum (Fig. 4a,b). This correlation allows for suggestion about the upstream swirl flow disruption and swirl air reversing from the biomass layer with enhanced formation of the axial downstream flow close to its centreline $(\mathrm{r} / \mathrm{R}=0)$. This process gradually decays to the minimum in the flame downstream regions - at $\mathrm{L} / \mathrm{D} \approx 0.3$ (Fig. 3a,c,e), with correlating decrease in the average values of axial flow (Fig. 4c). The effect is more pronounced when the secondary air supply rate is increased from $34 \mathrm{l} / \mathrm{min}$ to $90 \mathrm{l} / \mathrm{min}$, with correlating increase in air swirl number $S$ from 1.2 to 2 . This means that close to the flow axis there occurs a stagnation of the axial flow, with its reversing and formation of a central recirculation zone. Such zone forms at a high swirl level, which is confirmed by the numerical simulation of the non-reacting swirl flow dynamics. 

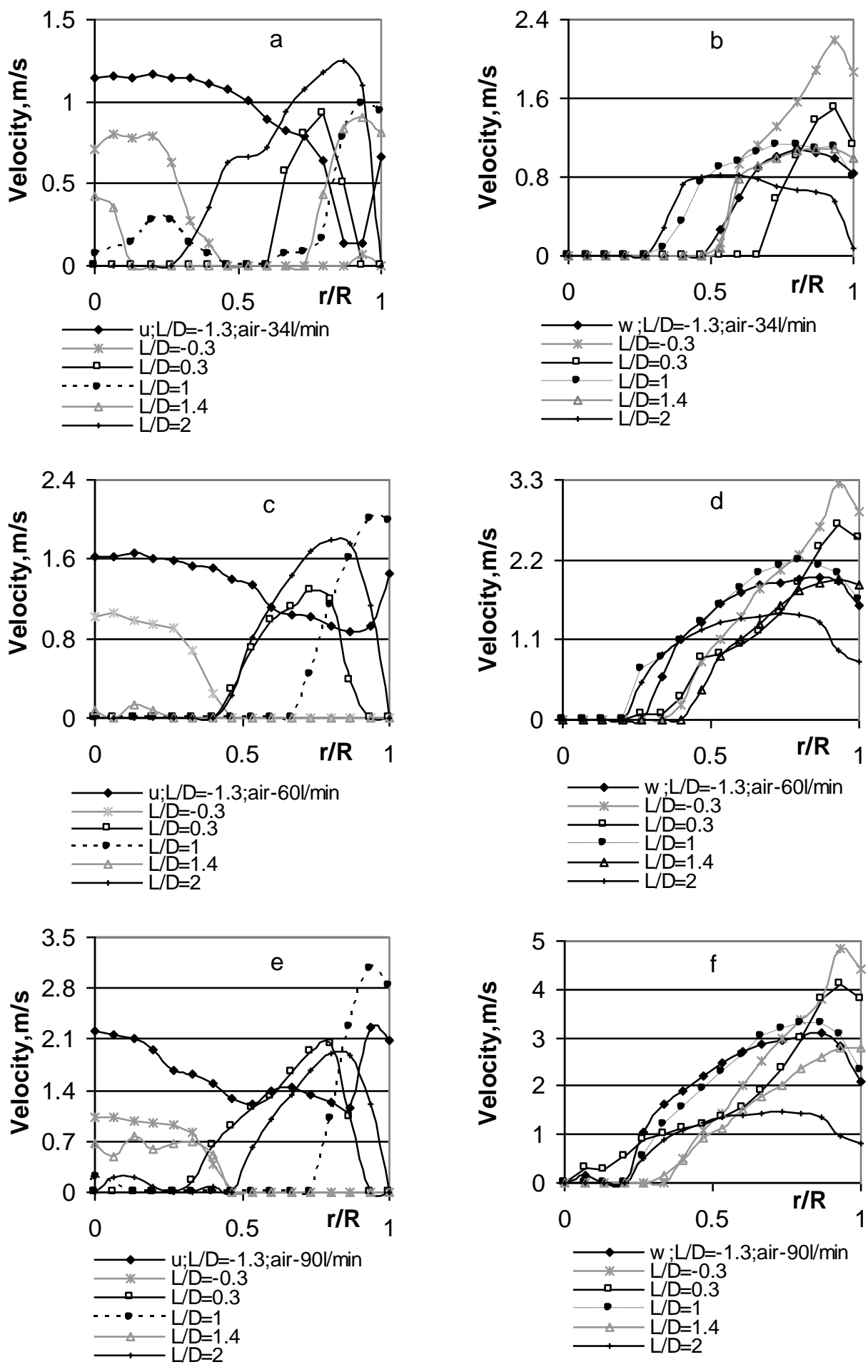

Fig. 3. The effect of swirling air supply on the formation of cold swirling air velocity profiles at different distances above and below the supply nozzles at a constant primary air supply rate $(30 \mathrm{l} / \mathrm{min})$ and different secondary air supply rates. 

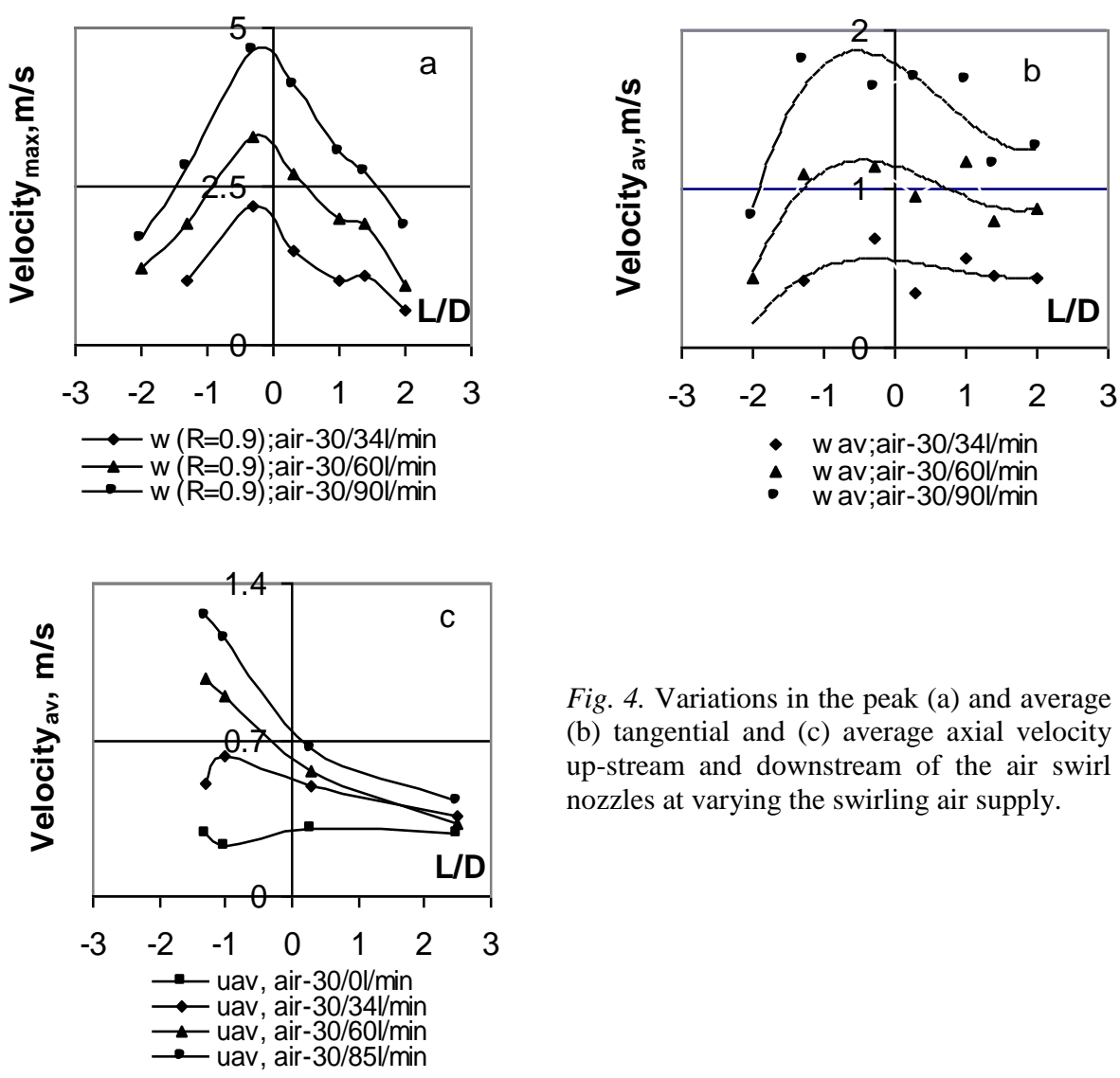

Fig. 4. Variations in the peak (a) and average (b) tangential and (c) average axial velocity up-stream and downstream of the air swirl nozzles at varying the swirling air supply.

\subsection{Numerical modelling of the non-reacting swirl flow dynamics.}

Development of the non-reacting swirling flow dynamics is described using the Navier-Stokes momentum and energy equations in standard form:

$$
\rho(\vec{u} \nabla) \vec{u}=\nabla(\mu \nabla \vec{u})+\vec{F},
$$

where $\rho$ is the flow density;

$\mu$ is its kinematic viscosity;

$\vec{u}$ is the velocity vector,

$\vec{F}$ is the external body force,

and

$$
\rho C_{p} \frac{\partial T}{\partial t}+\rho C_{p} \vec{u} \nabla T=\nabla(k \nabla T)+Q,
$$

where $C_{p}$ is the specific heat capacity,

$k$ is the heat conductivity,

$Q$ - the heat sources.

The numerical analysis of asymmetric non-reacting swirling flow dynamics $(Q=0)$ was carried out using a 2D description with account for the convective heat 
transfer to the channel walls, assuming their temperature to be constant and the primary axial air flow velocity to be $0.6 \mathrm{~m} / \mathrm{s}$. The rate of secondary swirling air supply was varied in the range $20-901 / \mathrm{min}$, whereas the L/D ratio below and above the swirling air inlet nozzle - from -1.5 up to 7 .

In accordance with the results of experiments on the cold swirling flow dynamics (Figs. 3 and 4) the numerical simulation also confirms the upstream swirl flow formation below the swirling air supply nozzle (L/D < 0$)$ with a swirl-induced increase in the upstream tangential flow velocity (up to the peak value) in proximity of the channel walls $(\mathrm{r} / \mathrm{R} \approx 0.9$, Fig. $5 b)$ and a correlating decrease in the minimum value of the axial flow velocity (Fig. $5 a$ ). Moreover, the results of numerical simulations confirm that the formation of upstream swirl motion promotes increase in the average and peak values of axial velocity close to the flow axis $(\mathrm{r} / \mathrm{R}=0$, Fig. $5 a)$, where the tangential velocity slows down to the minimum (Fig. $5 b$ ).
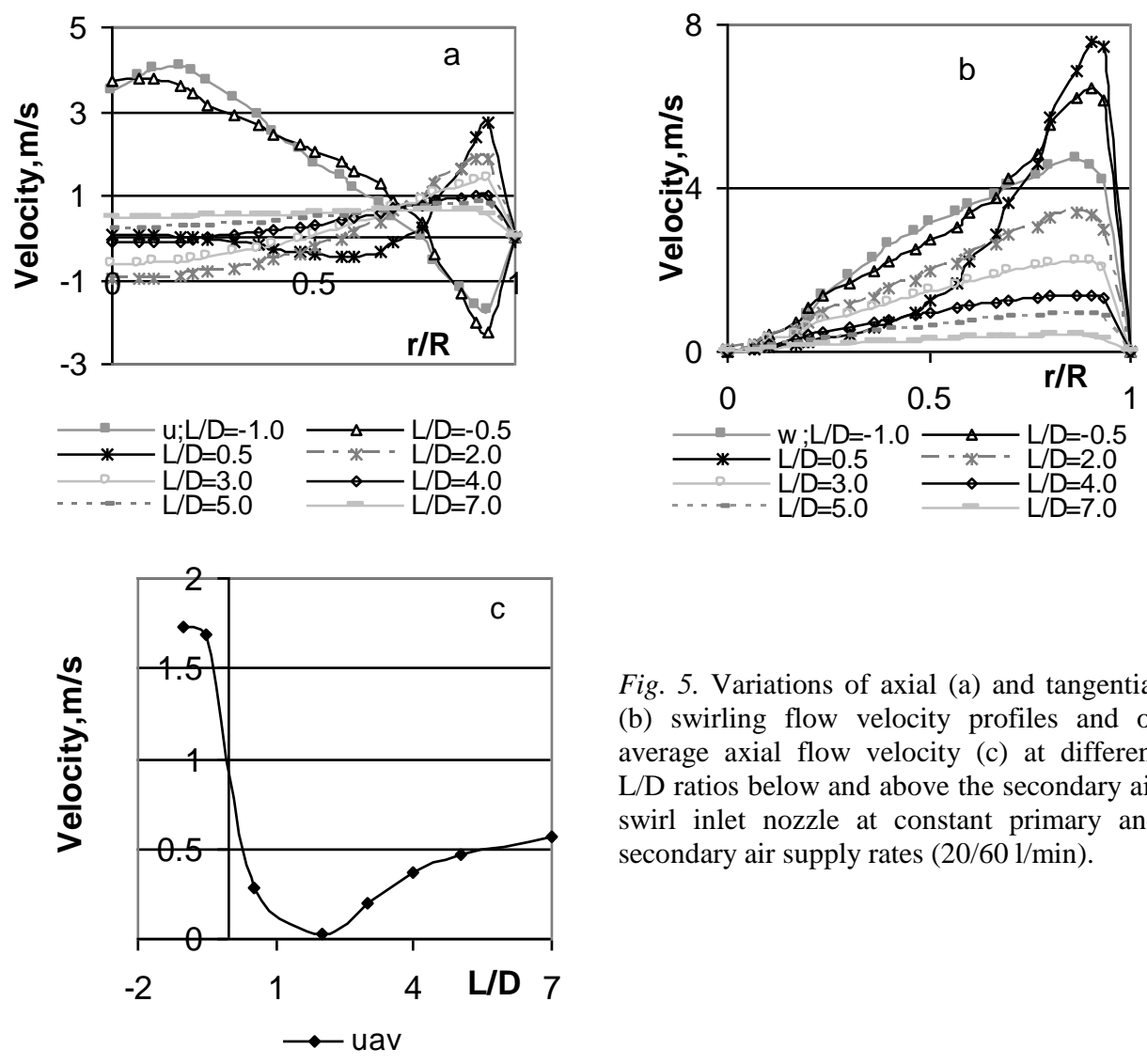

Fig. 5. Variations of axial (a) and tangential (b) swirling flow velocity profiles and of average axial flow velocity (c) at different $\mathrm{L} / \mathrm{D}$ ratios below and above the secondary air swirl inlet nozzle at constant primary and secondary air supply rates $(20 / 601 / \mathrm{min})$.

By analogy with the results of experiments on the cold non-reacting swirling flow dynamics, the average and peak values of the axial flow velocity below the secondary air nozzle strongly depend on the secondary air supply rate responsible for the swirl-enhanced formation of the upstream swirl motion, with correlating increase in the peak values of the reverse tangential flow velocity close to the 
channel walls, i.e. at $\mathrm{r} / \mathrm{R} \approx 0.9$ (Fig. $6 a-d$ ). As can be seen from Figs $5 a, b$, the swirl flow reversing below the air swirl nozzle slows down the axial flow velocity along the outside portion of the axial flow at $\mathrm{r} / \mathrm{R} \approx 0.9$, whereas enhances the axial downstream flow formation with the peak value in proximity of the flame axis at $\mathrm{r} / \mathrm{R} \approx 0-0.2$.

The opposite situation is observed above the air swirl nozzles - in the L/D range 1.5-4, where the swirl-induced axial flow reversing leads to formation of the axial recirculation zone with negative values of the axial flow (Figs. $5 b$ and $6 c, d$ ). The axial flow stagnation is observed at $\mathrm{L} / \mathrm{D} \approx 4-5$, where the swirl-induced axial downstream flow is completely balanced by the swirl-induced upstream flow. As follows from Fig. $6 c, d$, the axial flow reversing depends on the secondary air supply rate, which determines the intensity of secondary air swirling. The swirlenhanced recirculation with axial flow reversing is observed for the conditions when the secondary air supply rate exceeds $351 / \mathrm{min}$, i.e. the swirl number of the flow close to the nozzle outlet exceeds unity $(S>1)$.
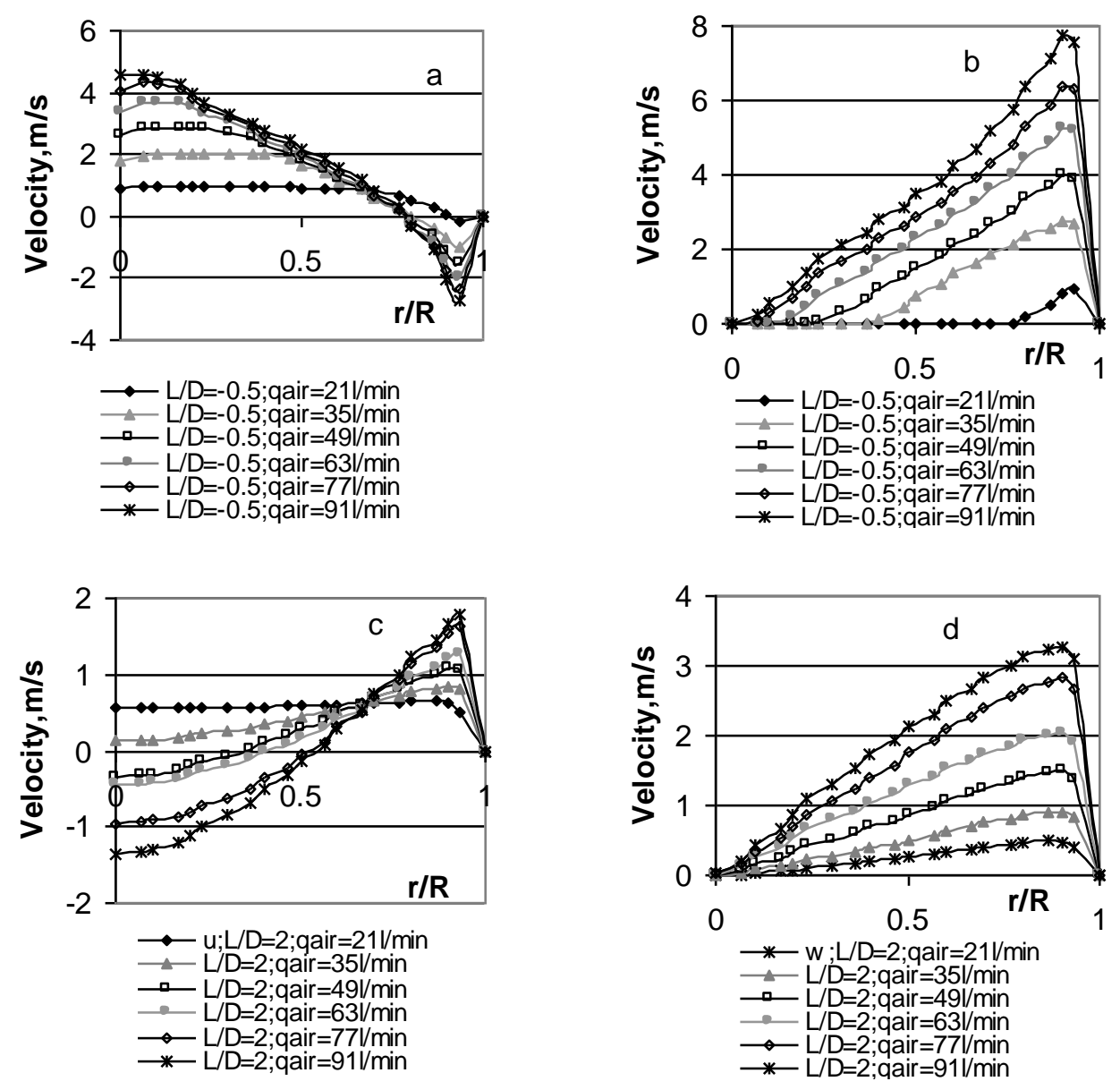

Fig. 6. The effect of secondary air supply on the formation of velocity profiles below $(\mathrm{L} / \mathrm{D}=-0.5)$ and above $(\mathrm{L} / \mathrm{D}=2)$ the swirling air nozzle. 


\subsection{Experimental study of the swirl flame dynamics.}

By analogy with the formation of cold non-reacting swirling flow structure, in the first stage the formation of swirling flame velocity field and flow structure below the swirling air nozzles is influenced by the upstream air swirl propagation near the channel walls with the peak value at $r / R \approx 0.9$, promoting there a decrease in the axial flow velocity; this is also influenced by enhanced convective transport of the flame species downstream of the flame axis, with the peak value of the axial flow velocity reached at $\mathrm{r} / \mathrm{R} \approx 0-0.2$ (Fig. $7 a, b$ ). In addition, the measurements of tangential velocity profiles indicate the formation of a secondary annular air swirl $(\mathrm{r} / \mathrm{R} \approx 0.2-0.5)$ which is generated at the reflection of upstream air swirl from the surface of biomass pellets. Consequently, the propagation of the upstream swirl flow near the channel walls leads to the formation of a very complicated structure of the flow field below the secondary air nozzles. This promotes the intensive mixing of the axial flow of volatiles $\left(\mathrm{CO}, \mathrm{H}_{2}\right.$, produced at biomass gasification) and the formation of a primary reaction zone near the flow axis (Fig. 7a). The formation of primary reactions below the swirling air nozzles is confirmed by measurements of the flow temperature: its peak value $(T \approx 1300-1400 \mathrm{~K})$ was reached above the wood pellet surface (close to it, $\mathrm{L} / \mathrm{D} \approx 0.1$ ) at the average flow temperature below the air nozzles $\mathrm{T} \approx 950-1000 \mathrm{~K}$.

As follows from Fig. $7 a, b$, the primary stage of swirling flow formation below the swirling air nozzles with upstream swirl-induced mixing of the reactants is distinguished by the flow field instability with local turbulent fluctuations of the velocity components. Factors responsible for the observed velocity fluctuations are as follows.

First, the propagation of upstream cold air swirl towards the biomass surface can cause local quenching of wood pellets. This, in turn, can lead to instability of thermal decomposition of biomass pellets responsible for the formation of main combustible volatiles - $\mathrm{CO}$ and $\mathrm{H}_{2}$ - with feedback of heat release fluctuations at their ignition and combustion in the form of generation of local turbulent velocity fluctuations. Besides, the surface roughness of biomass layer can contribute to the formation of turbulent fluctuations since near the surface of biomass pellets local vortices arise that can cause instability of the upstream air swirl mixing with axial flow of volatiles and correlating chemical kinetics fluctuations in the reacting mixture and flow velocity components.

The next stage of the swirling flame velocity field evolution close above the air swirl nozzles $(\mathrm{L} / \mathrm{D} \approx 0.3)$ shows the formation of large velocity gradients towards the flow axis (Fig. $7 c, d$ ). At this stage the flow field formation is influenced by two main factors: the formation of downstream swirl flow dynamics and the processes of chemical conversion of the flame components. Near the channel walls (at $r / R>0.5)$ the dominating effect is that of air jet outflow dynamics on the formation of velocity field. It is this effect that is mainly responsible for the formation of the peak values of axial and tangential velocities near the channel walls $($ at $\mathrm{r} / \mathrm{R} \approx 0.8-0.9$ ) indicating a linear dependence of the peak and average values of velocity components on the secondary air supply rate at the outlet of air 
swirl nozzles. Near the flame axis $(\mathrm{r} / \mathrm{R}<0.5)$ the formation of the flame velocity field is determined by the formation of a primary reaction zone that is developing at combustion of volatiles $\left(\mathrm{CO}, \mathrm{H}_{2}\right)$ and is initiated below the swirling air nozzles at upstream swirl-enhanced mixing of air with axial flow of volatiles and upstream swirl-induced axial convective downstream transport of the reactants.
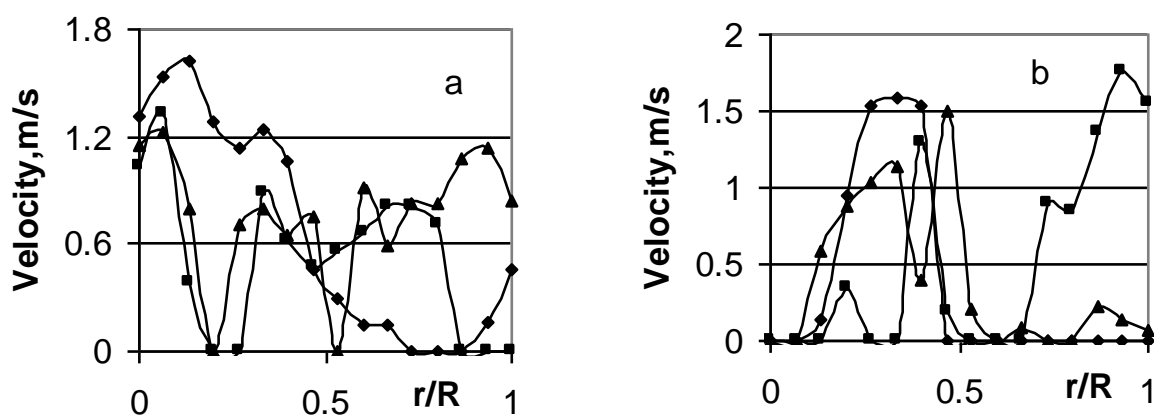

$\rightarrow \mathrm{u} ; \mathrm{L} / \mathrm{D}=-1.4 ; \mathrm{air}-30 / 34 \mathrm{l} / \mathrm{min}$

$\because \mathrm{w} ; \mathrm{L} / \mathrm{D}=-1.4 ; \mathrm{air}-30 / 34 \mathrm{l} / \mathrm{min}$ Z $w ; \mathrm{L} / \mathrm{D}=-1.4 ; \mathrm{air}-30 / 60 \mathrm{l} / \mathrm{min}$ $\rightarrow \quad \mathrm{u}: \mathrm{L} / \mathrm{D}=-1.4 ; \mathrm{air}-30 / 85 \mathrm{l} / \mathrm{min}$
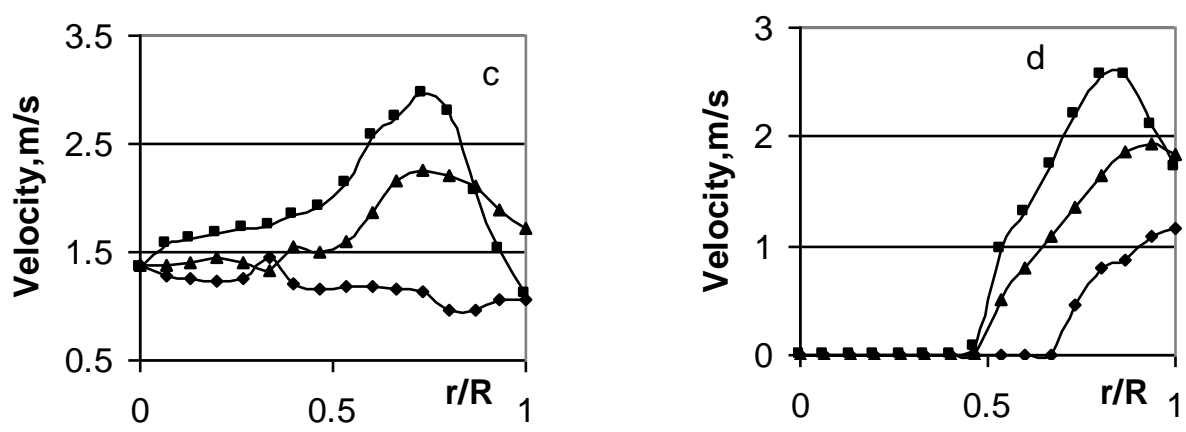

$\longrightarrow \mathrm{u}: \mathrm{L} / \mathrm{D}=0.3 ;$ air $-30 / 34 \mathrm{l} / \mathrm{min}$

$\mathrm{u} ; \mathrm{L} / \mathrm{D}=0.3 ;$ air-30/85 $\mathrm{l} / \mathrm{min}$

$\longrightarrow \mathrm{w} ; \mathrm{L} / \mathrm{D}=0.3 ;$ air-30/34 l/min

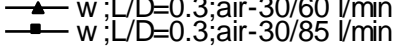
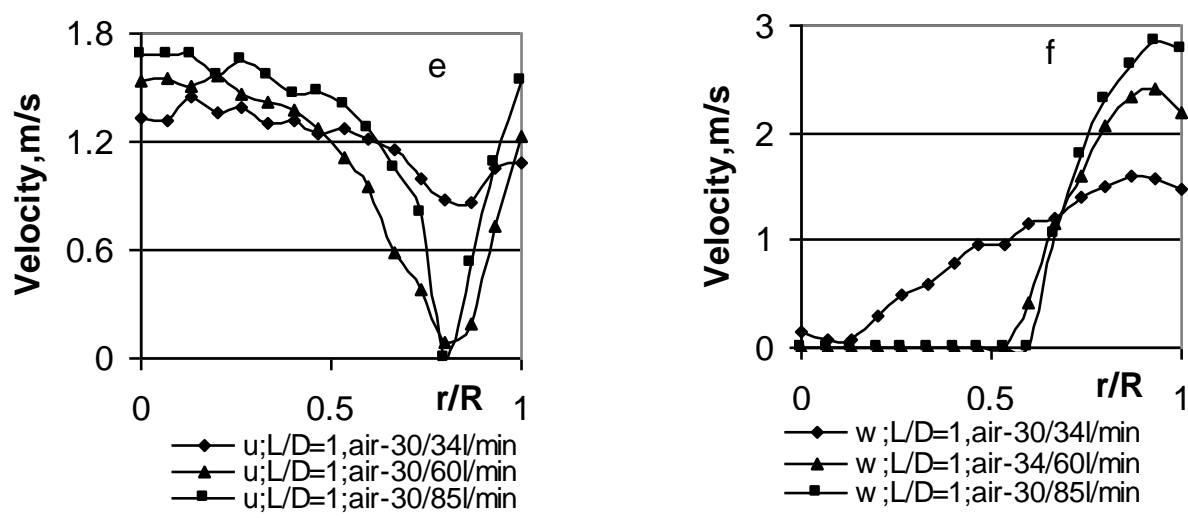

Fig. 7. The swirling flame velocity profiles below and above the swirling air nozzle at different secondary air supply rates. 
Stabilization of the swirling flame dynamics is observed further downstream $(\mathrm{L} / \mathrm{D}>1)$, where a pronounced separation of the effects occurs as related to the formation of axial downstream reaction zone and of downstream air swirl flow near the channel walls (Fig. 7e,f). At this stage of swirling flame formation the dominating effect is that of chemical conversion of volatiles on the velocity field formation with downstream air swirl-enhanced mixing of the axial volatile flow and the air directed along the outside part of the flame reaction zone. This leads to the radial expansion of the mentioned zone in the flame downstream regions up to $\mathrm{r} / \mathrm{R} \approx 0.8$, with correlating expansion of the axial velocity profiles, whereas gradually decreases the peak values of the air swirl intensity near the channel walls (Fig. 7e,f).

Analysis of the formation of swirling flame dynamics (Fig.7a-f) clearly shows that - in contrast to the non-reacting flows (Fig. 3a-f) indicating a fast decrease in the axial flow velocity in the downstream flow regions (Fig. 4c) - the development of a downstream reaction zone is associated with increased peak and average values of the axial velocity close to the swirling air nozzles (below and above, see Fig. $8 a, b)$ with correlating decrease in the peak and average values of the tangential velocity and respective decrease in the swirl intensity. The estimation of the air swirl number confirms this for equal main variable parameters - the primary and secondary air supply rates. The velocity field formation of swirling flame is developing at higher peak and average values of the axial velocity in the reaction zone, reduced swirl intensity and reduced flow swirl number $(\mathrm{S}<0.5)$ in comparison with cold non-reacting swirling flows. As a result, the development of swirling flame reaction zone prevents the formation of a recirculation zone, with axial flow stagnation near the flame base as observed for the cold flows and obtained from the results of numerical simulations of non-reacting flows (Fig. $6 c, d)$.
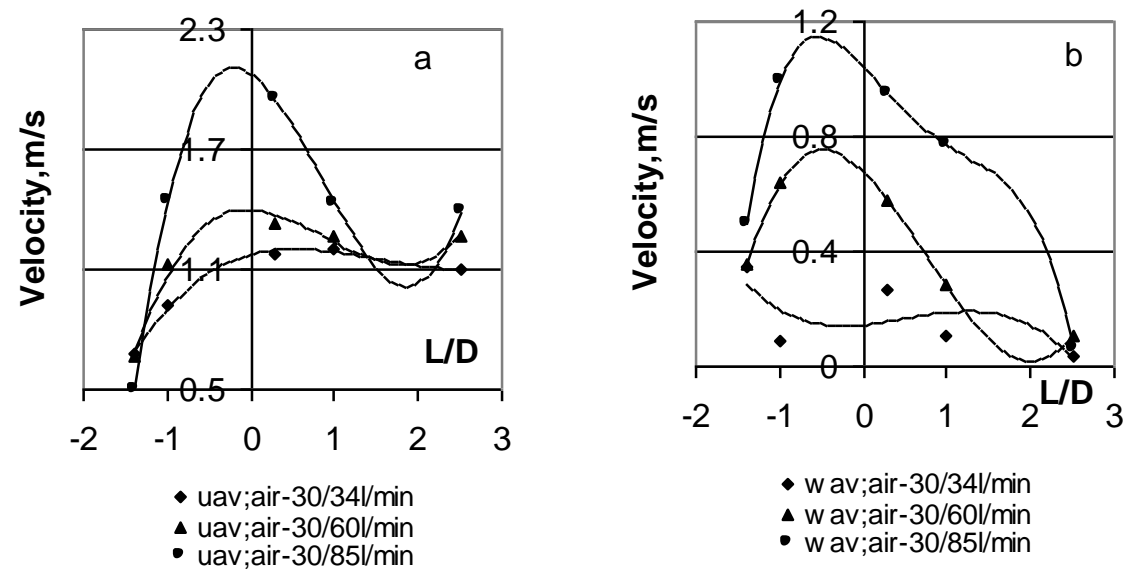

Fig. 8. The variations of the average axial (a) and tangential (b) swirl flame velocity components upstream and downstream of the air swirl nozzles at varying swirling air supply.

As shown above, formation of the velocity profiles of swirling flame is closely linked to the formation of a downstream axial reaction zone. Such inference follows from the results of measuring the flame temperature and composition profiles in the flame reaction zone indicating formation of the peak temperature values by combustion of volatiles $\left(\mathrm{CO}, \mathrm{H}_{2}\right)$, the volume fraction of the main 
product $\left(\mathrm{CO}_{2}\right)$, and the combustion efficiency close to the flame axis where the air excess decreases to the minimum (Fig. $9 a-d$ ).
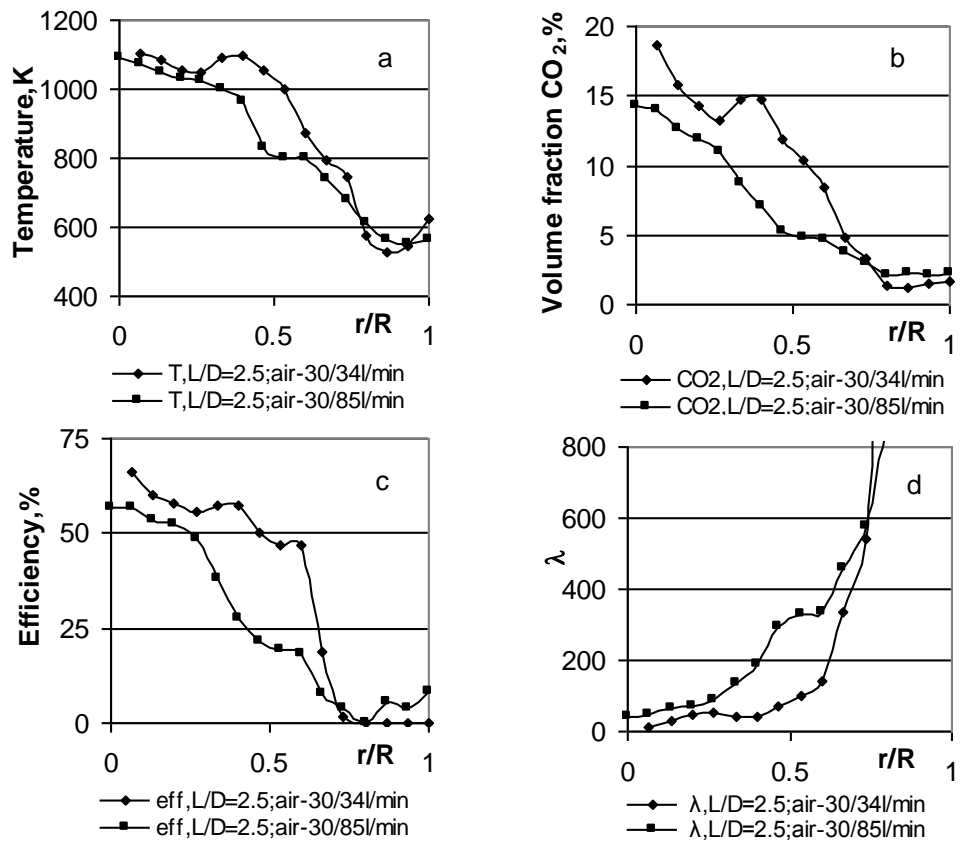

Fig. 9. Effect of the secondary swirling air supply on the flame temperature (a),

volume $\mathrm{CO}_{2}$ fraction (b), combustion efficiency (c), and air excess (d) in the flame reaction zone.

It should be noticed that the average value of the $\mathrm{CO}$ volume fraction in the flame reaction zone at the stage of chemical conversion is relatively high and approaches $1000 \mathrm{ppm}$, indicating incomplete combustion of $\mathrm{CO}$ up to $\mathrm{L} / \mathrm{D} \approx 2.5$. Two main factors limiting the development of chemical $\mathrm{CO}$ conversion are: the low average rate of thermal biomass decomposition $(d m / d t=0.12-0.15 \mathrm{~g} / \mathrm{s})$, which reduces the rate of $\mathrm{CO}$ formation; and, second, the low rate of $\mathrm{O}_{2}+\mathrm{CO}=\mathrm{O}+\mathrm{CO}_{2}$ reaction at the average temperature of $900-1000 \mathrm{~K}$ in the reaction zone, which slows down the rate of the main product $\left(\mathrm{CO}_{2}\right)$ formation with long-lasting reduction of the $\mathrm{CO}$ volume fraction in the downstream regions of the flame reaction zone (confirmed by the results of numerical simulation, see Fig. 10).

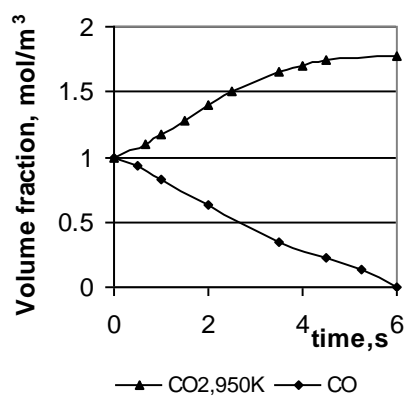

Fig. 10. Time-dependent variations in the $\mathrm{CO}_{2}$ and $\mathrm{CO}$ volume fractions at chemical $\mathrm{CO}$ conversion. 
Moreover, development of chemical conversion of volatiles downstream the reaction zone is affected by excessive air supplied to the flame. As follows from Fig. 9, increasing the secondary air supply rate results in a correlating increase of the air excess in the flame reaction zone, with decrease in the flame temperature, the volume fraction of the main product $\left(\mathrm{CO}_{2}\right)$ and the combustion efficiency. This, in turn, means a linear decrease (from $7.8 \mathrm{MJ} / \mathrm{kg}$ to $7 \mathrm{MJ} / \mathrm{kg}$ ) in the heat energy production at thermo-chemical conversion of biomass pellets. In contrast to the effect of secondary air supply rates on the temperature and composition profiles, here raising these rates causes a slight increase in the peak values of the axial velocity components (from $1.35 \mathrm{~m} / \mathrm{s}$ up to $1.7 \mathrm{~m} / \mathrm{s}$, Fig. $7 e, f$ ) in the flame reaction zone, indicating that the formation of the flame velocity field is influenced by upstream swirl-enhanced axial downstream flow formation (observed for the cold non-reacting flows, Figs. 3 and 4). The effect of upstream air swirl reversing on the swirling flame formation is confirmed by measurements of the flame temperature and composition profiles. The shape of these profiles indicate the formation of minor peaks at $\mathrm{r} / \mathrm{R} \approx 0.2-0.5$ that correlate with the formation of secondary air swirl below the air nozzles (Fig. $7 b$ ) and are generated at the upstream air swirl reflection from the wood pellets layer promoting enhanced mixing and chemical conversion of the volatiles. Moreover, the rapid increase in the air excess close to the channel walls evidences the incomplete mixing of swirling air flow with axial flow of volatiles at $\mathrm{L} / \mathrm{D} \approx 2.5$, which is confirmed by measurements of the flame velocity profiles indicating the formation of air swirl flow near the channel walls up to $\mathrm{L} / \mathrm{D} \approx 2.5$.

\section{CONCLUSIONS}

Conclusions that can be drawn from the results of experimental and numerical studies of non-reacting and reacting swirling flow formation along a cylindrical channel are as follows.

At the swirling air supply from the tangential nozzles the downstream and upstream swirl flow formation is detected, which directly affects the flow dynamics and combustion characteristics.

Development of the flow dynamics for the conditions of non-reacting flows is strongly influenced by the upstream swirl flow propagation near the channel walls promoting a correlating increase in the downstream flow velocity near the flow axis, with fast axial velocity decrease in the downstream flow regions. The reverse effect is observed at propagation of the downstream swirl flow near the channel walls, which promotes the formation of an axial recirculation zone with the reverse axial upstream flow formation that can completely balance the downstream axial flow.

By analogy with cold non-reacting flows, the development of the swirling flame dynamics is influenced by the upstream swirl-enhanced mixing of the main reactants in the space below the swirling air nozzle as well as by the development of a downstream axial reaction zone with an increase in the axial downstream flow velocity and a correlating decrease in the swirl intensity of the flame in comparison with cold non-reacting flows. Transition to the flow of lower swirl intensity prevents the formation of the recirculation zone at the flame base. 
The authors deeply acknowledge the financial support of the Latvian research grant $N r .623 / 1$

\title{
REFERENCES
}

1. Gupta, A.K., Lilley, D.G., \& Syred, N. (1984). Swirl Flows. Abacus Press UK), 588 p.

2. Meier, W., Duan, X.R., \& Weigand, P. (2006). Investigations of swirl flames in a gas turbine model combustor: turbulence-chemistry interactions. Combustion and Flame, 144, 225-236.

3. Külsheimer, C., \& Büchner, H. (2002). Combustion dynamics of turbulent swirling flames. Combustion and Flame, 131, 70-84.

4. Driscoll, J. F., \& Temme, J. (2011). Role of swirl in flame stabilization. In: $49^{\text {th }}$ AIAA Aerospace Sciences Meeting including the New Horizons Forum and Aerospace Exposition, AIAA 2011-108, 1-11.

5. Candel, S., Durox, D., Schuller, T., Palies, P., Bourgouin, J.F., \& Moeck, J. P. (2012). Progress and challenges in swirling flame dynamics. Comptes Rendus Mecanique, 340, 758-768.

6. Physics of Swirling Flow (2009). http://www.personal.psu.edu/users/y/x/yxw145/

7. Harvey, J.K. (1962). Some observations of the vortex breakdown phenomenon. J. Fluid Mechanics, 14, 585-592.

8. Fritz, J, Kroner, M., \& Sattelmayer, T. (2001). Flashback in a swirl burner with cylindrical premixing zone. Proceedings of ASME TURBO EXPO 2001, 2001GT-0054, p. 10.

9. Stöhr, M., Sadanandan, R., \& Meier, W. (2009). Experimental study of unsteady flame structures of an oscillating swirl flame in a gas turbine model combustor. Proceedings of Combustion Institute, 32, 2925-2932.

10. Cheng, R.K., Yegian, D.T., Miyasato, M.M., Samuelsen, G.S., Benson, C.E., Pellizzari, R., \& Loftus, P. (2000). Scaling and development of low-swirl burners for low-emission furnaces and boilers, Proceeding of the Combustion Institute, 28, 1305-1313. http://www2.lbl.gov/tt/publications/916pub1.pdf

11. Zaķe, M., Barmina, I., Descnickis, A., Krishko, V., \& Gedrovics, M. (2009). Experimental study of the combustion dynamics of renewable \& fossil fuel co-fire in swirling flame. Latvian Journal of Physics and Technical Sciences, 46(6), 3-16. http://versita.metapress.com/content/e175095347015913/fulltext.pdf

\section{VIRPUL̨PLŪSMU DINAMIKAS VEIDOŠANĀS EKSPERIMENTĀLIE UN SKAITLISKIE PĒTĪJUMI}

\author{
M. Abricka, I. Barmina, R. Valdmanis, M. Zaķe
}

\section{Kopsavilkums}

Ir veikti kompleksi aukstu nereaǵējošu un liesmas virpuļplūsmu dinamikas veidošanās eksperimentālie pētījumi, izvērtējot galvenos faktorus, kas ietekmē šo plūsmu dinamikas veidošanos cilindriskā kanālā virs granulēta biomasas slāņa pie aksiālas primārā gaisa padeves zem granulu slānna un gaisa virpuļ̣plūsmas padeves virs tā. Auksto virpuḷplūsmu pētījumi apliecina, ka plūsmas dinamiku būtiski ietekmē divu savstarpēji konkurējošu un pretēji vērstu virpul̦plūsmu veidošanās pie tangenciālās gaisa padeves sprauslas izejas. Lejupvērstā virpuḷplūsma, kas veidojas 
pie kanāla sienām, ierosina no granulu slāņa atstarotās augšupvērstas aksiālās plūsmas veidošanos, palielinot plūsmas aksiālo ātrumu, savukārt augšupvērstā tangenciālā plūsma veido pretēji vērstu aksiālo plūsmu, veidojot recirkulācijas zonu ar izteiktu aksiālās plūsmas stagnāciju tās centrālajā dą̧ā. Pie vienādiem primārā un sekundārā gaisa padeves nosacījumiem atšķirīga plūsmas dinamikas veidošanās ir konstatēta liesmas virpul̦plūsmai, kuras veidošanos būtiski ietekmē granulētas biomasas gazifikācija ar sekojošu gaistošo savienojumu uzliesmošanu un degšanas procesa veidošanos liesmas centrālajā dậā. Reversās virpuḷplūsmas veidošanās intensificē gaistošo savienojumu sajaukšanos ar gaisa virpuḷplūsmu, un stabila degšanas procesa veidošanos plūsmas centrālajā daļā ar korelējošu aksiālā plūsmas ātruma palielināšanos salīdzinot ar nereaǵējošo aukstā gaisa plūsmu, pie vienādiem šo plūsmu veidošanās sākuma nosacījumiem samazinot liesmas virpuḷskaitli un ierobežojot recirkulācijas zonas veidošanos degšanas zonas pamatnē.

18.06.2014. 